\title{
PENINGKATAN HASIL BELAJAR SISWA TENTANG PENGOLAHAN DATA MELALUI MODEL TALKING STICK
}

\section{Noviyanti M.}

STMIK Bina Nusantara Jaya Lubuklinggau, Indonesia,novivanti1986m@gmail.com

\section{ARTICLE INFORMATION}

Received: May 15, 2020

Revised: June 15, 2020

Available online: June 25, 2020

\section{KEYWORDS}

Talking Stick, Hasil Belajar

Talking Stick. The results of the Study

CORRESPONDENCE

\section{Riduan Febriandi}

E-mail: noviyanti1986m@gmail.com

\section{A $\quad$ B $\quad S \quad T \quad R$ A $\mathbf{C}$ T}

\begin{abstract}
Penelitian ini berjudul "Peningkatan Hasil Belajar Siswa Tentang Pengolahan Data Melalui Model Talking Stick". Masalah dalam penelitian ini adalah "Bagaimanakah model pembelajaran Talking Stick dapat meningkatkan hasil belajar siswa dalam pembelajaran Matematika?". Tujuan penelitian ini adalah untuk mengetahui bagaimanakah model pembelajaran talking stick dapat meningkatkan hasil belajar siswa. Serta tujuan jangka panjangnya adalah model ini dapat memotivasi siswa dalam belajar dan meningkatkan hasil belajarnya. Penelitian ini menggunakan penelitian kelas. Metode yang digunakan adalah Model Talking Stick. Populasinya adalah seluruh siswa kelas VI SDN 51 Lubuklinggau Tahun Pelajaran 2018/2019 yang berjumlah 27 siswa. Teknik pengumpulan data dengan teknik tes dan dapat disimpulkan bahwa hasil belajar tentang Pengolahan Data melalui model Talking Stick dapat meningkat.
\end{abstract}

This study entitled "improving student learning about the results of processing of Data Through the Model of the Talking Stick".The problem in this research is "How does the Talking Stick learning model can improve the learning results of students in learning mathematics?".The purpose of this research is to find out how the learning model talking stick can improve student learning outcomes.As well as your long-term goal is this model can motivate students in learning and improving the results of his studies.This research uses research class. The method used is a Model of the Talking Stick.Its population is a whole grade VI SDN 51 Lubuklinggau Year Lesson 2018/2019 of 27 students.Data collection techniques to techniques and tests can be concluded that the results of the study on the Data processing through the model of the Talking Stick can be increased.

\section{PENDAHULUAN}

Peraturan Pemerintah No.19 tahun 2005 tentang Standar Nasional Pendidikan pada Pasal 19 Ayat 1 menyebutkan bahwa proses pembelajaran pada satuan pendidikan diselenggarakan secara interaktif, inspiratif, menyenangkan, menantang, memotivasi peserta didik untuk berpartisipasi aktif, serta memberikan ruang yang cukup bagi prakarsa, kreativitas, dan kemandirian sesuai dengan bakat, minat, dan perkembangan fisik serta psikologis peserta didik. Salah satu mata pelajaran pada SD/MI/SDLB yang bertujuan untuk memberikan cara berpikir, menyusun pemikiran yang jelas, tepat dan teliti adalah mata pelajaran matematika. Berdasarkan Permendiknas No. 22 Tahun 2006, Mata pelajaran matematika bertujuan agar peserta didik memiliki kemampuan sebagai berikut: Memahami konsep matematika, menjelaskan keterkaitan antarkonsep dan mengaplikasikan konsep atau algoritma, secara luwes, akurat, efisien, dan tepat, dalam pemecahan masalah; Menggunakan penalaran pada pola dan sifat, melakukan manipulasi matematika dalam membuat generalisasi, menyusun bukti, atau menjelaskan gagasan dan pernyataan matematika; Memecahkan masalah yang meliputi kemampuan memahami masalah, merancang model matematika, 


\section{Journal of Mathematics Science and Education \\ | ISSN (Print) 2623-2375 | ISSN (Online) 2623-2383 | \\ DOI : https://doi.org/10.31540/jmse.v2i2.210 \\ Penerbit : LP4MK STKIP PGRI Lubuklinggau}

menyelesaikan model dan menafsirkan solusi yang diperoleh; Mengomunikasikan gagasan dengan simbol, tabel, diagram, atau media lain untuk memperjelas keadaan atau masalah.

Namun kenyataan dalam pembelajaran Matematika, pelaksanaannya belum mencapai hasil yang optimal. Pembelajaran Matematika yang ada saat ini lebih menekankan pemecahkan masalah yang meliputi kemampuan memahami masalah tetapi masih banyak siswa yang kurang berminat dan merasa sulit dalam pelajaran Matematika. Disamping itu Keterampilan guru dalam mengajar belum sepenuhnya dilaksanakan, seperti guru kurang variatif dalam menggunakan model dan media pembelajaran. Kondisi yang demikian mengakibatkan siswa tidak termotivasi dan belum mampu mengeksplorasi pengalaman belajarnya.

Fenomena pelaksanaan pembelajaran tersebut, merupakan gambaran yang terjadi di SD Negeri 51 Lubuklinggau. Berdasarkan refleksi awal dengan guru mitra melalui data dokumen dan observasi pada tanggal 1 Sepetember 2018, bahwa pelajaran Matematika pada Standar Kompetensi 4 yaitu Mengumpulkan dan mengolah data dengan Kompetensi Dasar 4.2 Mengolah dan menyajikan data dalam bentuk tabel, masih belum optimal. Hal ini disebabkan karena guru kurang menggunakan metode dan model pembelajaran yang bervariasi, kurangnya pemanfaatan media, kurangnya keaktifan siswa dan belum terciptanya pembelajaran yang menyenangkan.

Hal itu didukung data hasil belajar yang diperoleh siswa kelas VI SD Negeri 51 Lubuklinggau diketahui bahwa pada pelajaran Matematika, masih ada siswa yang kurang memahami pembelajaran ditunjukkan dengan data, dari 30 siswa ada 13 siswa (44\%) yang mendapatkan nilai di bawah Kriteria Ketuntasan Minimal (KKM) yaitu 66 sedangkan sisanya 17 siswa (56 \%) nilainya diatas KKM.

Berdasarkan diskusi peneliti dengan guru kelas VI, untuk memecahkan masalah pembelajaran Matematika pada Standar Kompetensi 4 yaitu Mengumpulkan dan mengolah data dengan 4.2 Mengolah dan menyajikan data dalam bentuk tabel, peneliti menetapkan alternatif tindakan untuk meningkatkan keterampilan guru, meningkatkan aktivitas siswa sehingga hasil belajar siswa meningkat. Maka peneliti menggunakan model pembelajaran Talking Stick. Model talking stick diterapkan dalam pembelajaran Matematika karena model talking stick mengarahkan proses pembelajaran Matematika menjadi proses pembelajaran yang menyenangkan, meningkatkan kreativitas guru dan siswa lebih terlibat dalam pembelajaran. Sehingga keterampilan guru, aktivitas siswa dan hasil belajar siswa dapat meningkat. 


\section{Journal of Mathematics Science and Education \\ ISSN (Print) 2623-2375 | ISSN (Online) 2623-2383 | \\ DOI : https://doi.org/10.31540/jmse.v2i2.210 \\ Penerbit : LP4MK STKIP PGRI Lubuklinggau}

Model talking stick diterapkan untuk memecahkan masalah dalam pembelajaran Matematika pada pada Standar Kompetensi 4 yaitu Mengumpulkan dan mengolah data dengan 4.2 Mengolah dan menyajikan data dalam bentuk tabel, karena model talking stick mendorong aktivitas siswa untuk lebih aktif dan siap untuk mengikuti proses pembelajaran Matematika. Dengan model ini juga, guru dituntut untuk lebih kreatif sehingga proses pembelajaran lebih menyenangkan dan hasil belajar dapat meningkat.

Langkah atau sintak dari model pembelajaran talking stick (Aqib, 2013:26) yaitu sebagai berikut: Guru menyiapkan sebuah tongkat; Guru menyampaikan materi pokok yang akan dipelajari, kemudian memberikan kesempatan kepada siswa untuk membaca dan mempelajari materi pada pegangannya atau paketnya; Setelah selesai membaca buku dan mempelajarinya guru mempersilakan siswa untuk menutup bukunya; Guru mengambil tongkat dan memberikan kepada siswa, setelah itu guru memberikan pertanyaan kepada siswa yang memegang tongkat tersebut harus menjawabnya, demikian seterusnya sampai sebagian besar siswa mendapat bagian untuk menjawab setiap pertanyaan daru guru; Guru memberikan kesimpulan; Evaluasi.

Tujuan penelitian adalah untuk mengetahui penerapan model pembelajaran talking stick dalam pembelajaran matematika materi pengolahan data pada siswa kelas VI SDN 51 Lubuklinggau.

\section{METODE}

Penelitian ini dilaksanakan di kelas VI SD Negeri 51 semester genap Lubuklinggau Tahun Ajaran 2018/2019 yang terletak di Jalan Jenderal Sudirman Kelurahan Kali Serayu Kecamatan Lubuklinggau Utara II Kota Lubuklinggau Kode Pos 31619. Penelitian Tindakan Kelas (PTK) ini dilaksanakan pada bulan November 2018 pada mata pelajaran Matematika materi tentang Pengolahan Data Melalui Model Talking Stick. Siklus yang dilakukan sebanyak dua kali, dan sebagai observernya adalah Kepala Sekolah, dan teman sejawat. Subjek penelitian ini adalah siswa kelas VI SD Negeri 51 Lubuklinggau dengan jumlah siswa sebanyak 27 siswa, yang terdiri dari 19 siswa laki-laki dan 8 siswa perempuan, yang tercatat pada tahun ajaran 2018/2019 rincian siswa dalam penelitian ini dapat dilihat pada tabel 3.1 berikut: 
Tabel 3. Rincian Jumlah Siswa Kelas VI SD Negeri 51 Lubuklinggau

\begin{tabular}{ccccc}
\hline \multirow{2}{*}{ No } & \multirow{2}{*}{ Kelas } & \multicolumn{2}{c}{ Jenis Kelamin } & \multirow{2}{*}{ Jumlah } \\
\cline { 3 - 4 } & & Laki-laki & Perempuan & \\
\hline 1. & VI & 19 & 8 & 27 \\
\hline & Jumlah & $\mathbf{1 9}$ & $\mathbf{8}$ & $\mathbf{2 7}$
\end{tabular}

Sumber: Tata usaha SD Negeri 51 Lubuklinggau

Sumber data dalam penelitian ini ialah berasal dari kegiatan pembelajaran di kelas yang dilakukan oleh guru beserta siswa kelas VI SD Negeri 51 Lubuklinggau. Sedangkan data berupa (1) hasil belajar, (2) observasi guru, dan (3) observasi siswa diperoleh melalui tes, baik tes siklus I maupun tes siklus II, serta hasil observasi.Teknik untuk mengumpulkan data dalam Penelitian Tindakan Kelas (PTK) ini menggunakan teknik tes. Teknik tes digunakan untuk mengetahui hasil belajar siswa dan mendapatkan data utama berupa skor atau nilai tentang Pengolahan Data dengan menerapkan model Talking Stick. Tes yang akan digunakan berbentuk pilihan essay berjumlah 5 soal. Tes dilakukan sebanyak dua kali yaitu siklus I dan siklus II. Pada masing-masing siklus dilakukan dua kali pertemuan.

Teknik pengecekan data dan keabsahan data, penulis menggunakan teknik pemeriksaan keabsahan data yang memanfaatkan pengamat (observer) untuk keperluan pengecekan pelaksanaan tindakan dalam pembelajaran, di samping ditunjukkan oleh hasil penilaian terhadap kemampuan siswa tentang Pengolahan Data Melalui Model Talking Stick. Data observasi untuk mengetahui kesesuaian antara pelaksanaan tindakan yang sedang berlangsung dan diharapkan dapat menghasilkan perubahan yang diinginkan. Observasi yang akan diamati adalah pelaksanaan pembelajaran dan aktivitas belajar siswa. Oleh karena itu, kegiatan observasi dilakukan oleh observer yang terdiri dari Kepala sekolah dan teman sejawat yang bertugas menilai pelaksanaan pembelajaran dan menilai aktivitas proses belajar siswa. Dengan menjelaskan hasil penelitian yang berupa nilai kemampuan siswa tentang Pengolahan Data yang disertai hasil pengamatan para observer maka meningkatkan tingkat kepercayaan data yang diperoleh dalam penelitian ini. Aspek yang dinilai pada saat observasi pelaksanaan pembelajaran dapat di lihat pada lampiran.

Data nontes yang diperoleh dari lembar observasi siklus I maupun siklus II dijadikan sebagai pedoman tertulis atau dapat dijadikan dasar untuk melihat peningkatan ketuntasan dan efektivitas 


\section{Journal of Mathematics Science and Education \\ | ISSN (Print) 2623-2375 | ISSN (Online) 2623-2383 | \\ DOI : https://doi.org/10.31540/jmse.v2i2.210 \\ Penerbit : LP4MK STKIP PGRI Lubuklinggau}

model Talking Stick pada materi Pengolahan Data yang dilakukan peneliti kepada siswa kelas VI SD Negeri 51 Lubuklinggau Tahun Ajaran 2018/2019 setelah kegiatan pembelajaran.

Teknik analisis data yang digunakan dalam penelitian ini adalah teknik analisis data sederhana yang dihitung berdasarkan jumlah perolehannya. Analisis data yang digunakan adalah dengan membandingkan hasil penilaian pratindakan, hasil penilaian siklus I, hasil penilaian siklus II. Nilai-nilai tersebut akan dimunculkan dalam tabel. Keberhasilan tindakan dapat dilihat dari peningkatan kualitas proses pembelajaran dan peningkatan nilai hasil pembelajaran. Jika siswa memperoleh nilai $\geq 65$ maka siswa tersebut dinyatakan tuntas secara individual. Dan apabila nilai rata-rata siswa secara keseluruhan mencapai $85 \%$ memperoleh nilai $\geq 65$ maka pembelajaran dinyatakan berhasil.

\section{HASIL DAN PEMBAHASAN}

Penelitian yang peneliti laksanakan diawali dengan kegiatan pratindakan yang dilakukan pada tanggal 1 November 2018. Pada kegiatan pratindakan ini, peneliti belum melaksanakan tugas sebagai guru yang profesional untuk memiliki keterampilan yang memadai dalam mengembangkan berbagai metode, strategi, model, maupun teknik pembelajaran yang efektif, aktif, kreatif, dan menyenangkan sebagaimana diisyaratkan dalam Kurikulum Tingkat Satuan Pendidikan (Komalasari, 2010:58). Dalam pratindakan peneliti hanya menggunakan metode ceramah saja dan tanpa alat atau media yang mampu menarik perhatian siswa untuk belajar sehingga kegiatan belajar mengajar menjadi tidak aktif, kurang efektif, dan tidak menyenangkan bahkan cenderung membosankan sehingga siswa merasa tidak betah dan kurang semangat dalam belajar. Hal ini berdampak pada ketidaktuntasan belajar siswa.

Hasil belajar siswa dari data yang diperoleh 27 orang siswa, yang tuntas 13 orang dengan persentase sebesar 48,15\%. Dan siswa yang memperoleh nilai <65 atau belum tuntas berjumlah 14 orang dengan persentase sebesar 51,85\% dengan nilai rata-rata siswa pada pratindakan adalah 59,81. Berdasarkan hasil ini, kegiatan pratindakan ini dinyatakan belum berhasil. Maka daripada itu, peneliti melaksanakan siklus selanjutnya.

Siklus I dilaksanakan pada tanggal 5 November 2018. Pada kegiatan siklus I, peneliti tidak hanya menggunakan metode ceramah saja tetapi juga menggunakan model Talking Stick pada materi Pengolahan Data. Sengaja peneliti memilih model Talking Stick karena menurut (Suprijono, 2009:109) "pembelajaran dengan model Talking Stick mendorong peserta didik untuk berani 


\section{Journal of Mathematics Science and Education \\ ISSN (Print) 2623-2375 । ISSN (Online) 2623-2383 । \\ DOI : https://doi.org/10.31540/jmse.v2i2.210 \\ Penerbit : LP4MK STKIP PGRI Lubuklinggau}

mengemukakan pendapat". Pembelajaran dengan model Talking Stick diawali oleh penjelasan guru mengenai materi pokok yang akan dipelajari. Peserta didik diberi waktu dan kesempatan untuk mempelajari materi. Guru mengambil tongkat yang telah dipersiapkan dan tongkat tersebut diberikan kepada salah satu peserta didik. Peserta didik yang menerima tongkat tersebut diwajibkan menjawab pertanyaan dari guru. Langkah akhir dari model Talking Stick adalah guru memberikan kesempatan kepada peserta didik melakukan refleksi terhadap materi yang telah dipelajarinya. Guru memberi ulasan terhadap seluruh jawaban yang diberikan peserta didik, selanjutnya bersama-sama merumuskan kesimpulan. Dengan begitu, para siswa nantinya akan lebih mudah untuk menciptakan gagasannya.

Ternyata, pendapat dari beberapa para ahli di atas yang mengungkapkan bahwa model Talking Stick dapat meningkatkan hasil belajar siswa terbukti kebenarannya. Dikarenakan penelitian yang penulis lakukan pada materi Pengolahan Data siswa kelas VI SD Negeri 51 Lubuklinggau mengalami peningkatan yang cukup signifikan dibandingkan pada hasil pratindakan yang tidak menggunakan model Talking Stick.

Hal ini dibuktikan pada hasil tindakan siklus I, nilai rata-rata siswa mencapai 64,26 dan ketuntasan belajar mencapai 70,37\%, dengan jumlah siswa yang tuntas sebanyak 19 orang dan yang tidak tuntas sebanyak 8 orang, dengan peningkatan ketuntasan dari pratindakan ke siklus I sebesar 4,45 untuk nilai rata-rata siswa dan ketuntasan belajar siswa meningkat sebesar $22.22 \%$. Walaupun telah terjadi peningkatan pada hasil tes siklus I, namun kegiatan pembelajaran masih belum berhasil dikarenakan ketuntasan belajar siswa belum mencapai 85\%. Akan tetapi, peneliti akui bahwa faktor ketidaktuntasan belajar siswa ini bukan karena model Talking Stick yang tidak bagus atau tidak cocok melainkan faktor dari peserta didik dan peneliti sendiri. Di antaranya, siswa masih kurang serius dalam mengikuti pembelajaran dikarenakan mereka belum fokus dalam belajar, dan masih ada beberapa siswa semangatnya masih kurang dikarenakan guru belum memberikan motivasi secara maksimal kepada siswa. Oleh karena itu, peneliti perlu mengadakan kembali siklus ke II.

Siklus II dilaksanakan pada tanggal 22 November 2018. Pada siklus II, peneliti melakukan perbaikan dari kekurangan yang ada pada siklus I. Di antaranya peneliti menjadikan suasana belajar yang menyenangkan sehingga siswa menjadi lebih semangat dalam mengikuti pelajaran. Akhirnya, penelitian yang peneliti lakukan pada siklus II ini berhasil materi Pengolahan Data karena hasil tes pada siklus II nilai rata-rata mencapai 71,48 dan tingkat ketuntasan mencapai $88,89 \%$, dengan jumlah siswa yang tuntas sebanyak 24 orang dan yang tidak tuntas sebanyak 3 orang. Perbandingan 


\section{Journal of Mathematics Science and Education \\ ISSN (Print) 2623-2375 | ISSN (Online) 2623-2383 DOI : https://doi.org/10.31540/jmse.v2i2.210 \\ Penerbit : LP4MK STKIP PGRI Lubuklinggau}

hasil tes pada materi Pengolahan Data kelas VI SD Negeri 51 Lubuklinggau Tahun Ajaran 2018/2019 untuk lebih jelasnya dapat dilihat dari tabel berikut:

Tabel 4. Perbandingan Hasil Akhir Tes Pratindakan, Siklus I dan Siklus II

\begin{tabular}{|c|c|c|c|c|c|c|c|}
\hline \multirow{2}{*}{ No } & \multirow{2}{*}{$\begin{array}{c}\text { Pelaksanaan } \\
\text { Tindakan }\end{array}$} & \multirow{2}{*}{$\begin{array}{c}\text { Jumlah } \\
\text { Siswa } \\
\text { Tes }\end{array}$} & \multicolumn{2}{|c|}{$\begin{array}{c}\text { Tuntas } \\
\geq 65\end{array}$} & \multicolumn{2}{|c|}{$\begin{array}{c}\text { Belum Tuntas }< \\
65\end{array}$} & \multirow{2}{*}{$\begin{array}{r}\text { Nilai } \\
\text { Rata- } \\
\text { rata }\end{array}$} \\
\hline & & & $\begin{array}{c}\text { Jlh } \\
\text { Siswa }\end{array}$ & $\%$ & $\begin{array}{c}\text { Jlh } \\
\text { Siswa }\end{array}$ & $\%$ & \\
\hline 1 & Pratindakan & 27 & 13 & $48,15 \%$ & 14 & $51,85 \%$ & 59,81 \\
\hline 2 & Siklus I & 27 & 19 & $70,37 \%$ & 8 & $29,63 \%$ & 64,26 \\
\hline 3 & Siklus II & 27 & 24 & $88,89 \%$ & 3 & $11,11 \%$ & 71,48 \\
\hline
\end{tabular}

Di bawah ini disajikan grafik peningkatan persentase ketuntasan siswa dan peningkatan ratarata nilai siswa pada materi Pengolahan Data.

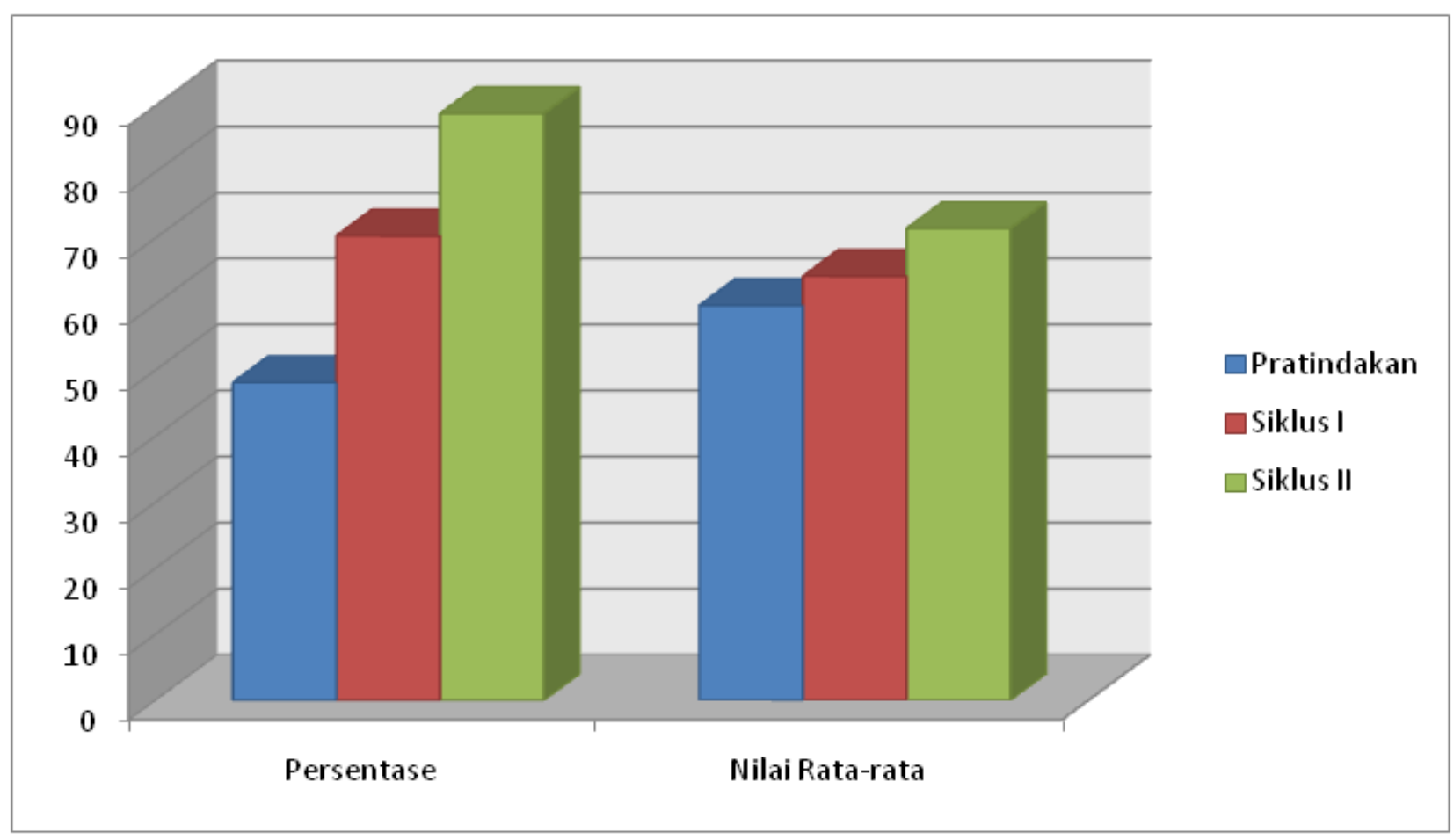

Grafik 1. Peningkatan Persentase Ketuntasan dan Peningkatan Rata-Rata Nilai Siswa

Dari grafik 1 di atas berarti dari siklus I sampai siklus II nilai rata-rata siswa meningkat sebesar 7,22 atau dengan ketuntasan belajar sebesar 18,52\%. Dan dari pratindakan sampai siklus II 


\section{Journal of Mathematics Science and Education \\ | ISSN (Print) 2623-2375 | ISSN (Online) 2623-2383 | \\ DOI : https://doi.org/10.31540/jmse.v2i2.210 \\ Penerbit : LP4MK STKIP PGRI Lubuklinggau}

nilai rata-rata siswa telah meningkat sebesar 11,67 atau dengan ketuntasan belajar sebesar 40,74\%. Berikut ini peneliti sajikan uraian peningkatan antar tindakan:

a. Peningkatan persentase ketuntasan belajar siswa dari pratindakan ke siklus I:

$$
\mathrm{P}=\frac{64,26-59,81}{59,81} \times 100 \%=7,44 \%
$$

b. Peningkatan persentase ketuntasan belajar siswa dari siklus I ke siklus II:

$$
\mathrm{P}=\frac{71,48-64,26}{64,26} x 100 \%=11,24 \%
$$

c. Peningkatan persentase ketuntasan belajar siswa dari pratindakan ke siklus II:

$$
\begin{aligned}
& \mathrm{R}_{2}=\frac{71,48+64,26}{2}=67,87 \\
& \mathrm{P}=\frac{67,87-59,81}{59,81} \times 100 \%=13,48 \%
\end{aligned}
$$

Peningkatan hasil belajar siswa kelas VI SD Negeri 51 Lubuklinggau Tahun Ajaran 2018/2019 pada materi Pengolahan Data dari tes pratindakan sampai siklus II yaitu 13,48\% dan ketuntasan hasil belajar secara klasikal sebesar $88,89 \%$.

Hasil akhir tes pembelajaran siklus II telah mencapai Kriteria Ketuntasan Minimal (KKM) yang ditetapkan sekolah dengan persentase ketuntasan klasikal 88,89\% dari jumlah siswa telah mendapat nilai $\geq 65$. Berdasarkan peningkatan hasil belajar siswa dari pratindakan sampai siklus II, maka dapat disimpulkan bahwa penerapan model Talking Stick terbukti dapat meningkatkan hasil belajar siswa kelas VI SD Negeri 51 Lubuklinggau Tahun Ajaran 2018/2019 pada materi Pengolahan Data.

\section{KESIMPULAN}

Berdasarkan hasil dan pembahasan di atas dapat disimpulkan bahwa penerapan model pembelajaran talking stick dalam pembelajaran matematika dapat meningkatkan hasil belajar siswa SD Negeri 51 Lubuklinggau pada materi pengolahan data. 


\section{Journal of Mathematics Science and Education \\ ISSN (Print) 2623-2375 | ISSN (Online) 2623-2383 \\ DOI : https://doi.org/10.31540/jmse.v2i2.210 \\ Penerbit : LP4MK STKIP PGRI Lubuklinggau}

\section{DAFTAR RUJUKAN}

Aqib, Zainal. 2013. Model-model Medi, dan Strategi Pembelajaran Kontekstual (Inovatif). Bandung: Yrama Widya.

Dimyati dan Mudjiono. 2009. Belajar dan Pembelajaran. Jakarta: PT. Asdi Mahasetya.

Komalasari, 2010, Cooperative Learning. Nusa Media: Bandung,

Sanjaya, Wina. 2009. Strategi Pembelajaran Berorientasi Standar Proses Pendidikan.Jakarta: Kencana.

Suprijono, Agus. 2013. Cooperative Learning. Teori dan Aplikasi Paikem. Jakarta: Pustaka Pelajar.

Suyatno. 2009. Menjelajah Pembelajaran Inovatif. Sidoarjo : Mas Media Buana Pustaka.

Uno, Hamzah B. 2007. Model Pembelajaran Menciptakan Proses Belajar-Mengajar yang Kreatif dan Efektif. Jakarta: Bumi Aksara. 